\title{
PENGARUH PENGGUNAAN GAMBAR SERI TERHADAP KETERAMPILAN MENULIS CERITA MURID KELAS III SD INPRES BONTOKANANG KECAMATAN GALESONG KABUPATEN TAKALAR
}

\author{
Herlinda, Munirah, Abdan Syakur. \\ Pendidikan Guru Sekolah Dasar, Fakultas Keguruan dan Ilmu Pendidikan \\ Universitas Muhammadiyah Makassar \\ Iqramsyar34@gmail.com
}

\begin{abstract}
ABSTRAK
Jenis penelitian ini adalah penelitian Pra-eksperimen bentuk pretest dan Postest Desain yaitu sebuah eksperimen yang dalam pelaksanaanya hanya melibatkan satu kelas sebagai kelas eksperimen tanpa adanya kelas pembanding (kelas kontrol) yang bertujuang mengetahui pengaruh penggunaan gambar seri terhadap keterampilan menulis cerita murid kelas III SD Inpres Bontokanang Kecamatan Galesong Kabupaten Takalar tahun ajaran 2016-2017. Satuan eksperimen dalam penelitian ini adalah murid kelas III sebanyak 20 orang. Penelitian dilaksanakan selama lima kali pertemuan. Keberhasilan proses pembelajaran ditinjau dari aspek yaitu: keterampilan ketuntasan hasil belajar bahasa Indonesia murid secara klasikal, aktifitas siswa dalam pembelajaran bahasa Indonesia. Pembelajaran dikatakan berhasil jika aspek diatas terpenuhi. Tehnik pengumpulan data yang digunakan adalah data skor perolehan hasil keterampilan menulis cerita murid yang dikumpulkan dengan menggunakan test melalui media gambar seri, data tentang aktifitas murid dalam pembelajaran bahasa Indonesia dikumpulkan dengan menggunakan lembar observasi aktivitas belajar murid. Hasil analisis stastistik deskriptif penggunaan media gambar seri terhadap keterampilan menulis cerita murid positif, keterampilan menulis cerita murid dengan menggunakan media gambar seri menunjukkan hasil belajar yang lebih baik dari pada sebelum diterapkan media gambar seri. Hasil analisis statistik inferensial menggunakan rumus uji-t, diketahui bahwa nilai $t_{\text {Hitung yang }}$ diperoleh adalah 9, 30 dengan frekuensi $\mathrm{db}=20-1=19$, pada taraf signifikansi $5 \%$ diperoleh $\mathrm{t}$ Tabel $=2$ 2,09. Jadi, $t$ Hitung $>t_{\text {Tabel }}$ atau hipotesis nol $\left(\mathrm{H}_{0}\right)$ ditolak dan hipotesis alternative $\left(\mathrm{H}_{1}\right)$ diterima. Hal ini membuktikan bahwa ada pengaruh penggunaan gambar seri terhadap keterampilan menulis cerita murid kelas III SD Inpres Bontokanang Kecamatan Galesong Kabupaten Takalar.
\end{abstract}

Kata Kunci: Eksperimen, Gambar Seri dan Keterampilan Menulis Cerita 


\section{PENDAHULUAN}

Salah satu upaya untuk mewujudkan tujuan dari pendidikan ini adalah dengan melalui Pembelajaran bahasa Indonesia di Sekolah Dasar. Pembelajaran Bahasa Indonesia di Sekolah Dasar (SD) berdasarkan Kurikulum Tingkat Satuan Pendidikan (KTSP) lebih menekankan keterlibatan anak dalam belajar, hal ini terlihat dalam standar kompentensi yang harus dikuasai oleh murid yaitu kompentensi mendengarkan, berbicara, membaca dan menulis (Depdiknas, 2006:22), khususnya keterampilan dibidang menulis di SD perlu ditingkatkan guna kelanjutan menulis pada jenjang yang lebih tinggi.

Kemampuan menulis di SD tidak diperoleh dari hasil begitu saja akan tetapi memerlukan tahap - tahap pembelajaran yang membutuhkan waktu yang tidak sedikit tetapi membutuhkan proses yang cukup lama proses yang dilakukan oleh murid dalam melatih menulis dipermulaan yang secara formal dilakukan melalui pembelajararan bahasa Indonesia yang dimulai sejak SD. Dalam kurikulum satuan pendidikan (KTSP) ada empat standar kompetensi yang harus dimiliki oleh seorang murid sebagai kemampuan dasar yaitu kemampuan standar kompetensi mendengarkan, membaca, bercerita, dan menulis.

Menulis merupakan salah satu kemampuan yang perlu dimiliki oleh murid Sekolah Dasar terutama pada murid kelas awal yaitu kelas I s/d III. Dengan memiliki kemampuan menulis, murid dapat mengkomunikasikan ide, penghayatan, dan pengalamannya ke berbagai pihak. Di samping itu, murid pun dapat meningkatkan dan memperluas pengetahuannya melalui tulisan-tulisan.

Salah satu upaya yang bisa dilakukan oleh seorang guru dalam proses pembelajaran agar murid lebih aktif dan kreatif dalam pembelajaran bahasa Indonesia khususnya meningkatkan keterampilan menulis cerita di kelas III yaitu dengan menggunakan media gambar seri dalam pembelajaran bahasa Indonesia.

Sebagai mana di ketahui Peranan media gambar seri dalam menulis dapat membantu murid untuk melihat hubungan antara konsep, peristiwa dan tokoh yang ada dalam pelajaran, dengan media gambar seri pula murid lebih mudah melihat hubungan antara berbagai komponen suatu teori atau isi pelajaran. Dengan bantuan media gambar seri guru lebih mudah 
mengatasi hambatan-hambatan yang mengganggu perhatian murid di kelas.

Penggunaan media gambar seri pada pembelajaran dapat mempermudah murid menerima pelajaran karena murid dapat memahami lewat apa yang dilihatnya dalam media gambar itu.

Oleh karena itu, peneliti melakukan observasi langsung di SD Inpres Bontokanang Kec.Galesong Kab.Takalar dengan hasil observasi pada umumnya murid kelas III di sekolah dasar tersebut kurang terampil dalam hal menulis cerita pada pembelajaran bahasa Indonesia, disamping itu murid yang mengikuti pembelajaran kurang bersemangat karena guru kurang melibatkan murid dalam PBM, hal ini ditemukan peneliti dari hasil observasi yang dilakukan dalam setting Kelas III di sekolah dasar tersebut yang berdampak pada kurangnya keaktifan murid dalam pembelajaran menulis, sehingga temuan peneliti secara umum dapat di uraikan sebagai berikut: (1) guru kadang kala hanya menyuruh murid menulis cerita tentang pengalamannya tanpa ada konsep awal yang jelas, tentang menulis cerita (2) apabila guru mengajar kurang melibatkan murid secara langsung dalam KBM yang dilaksanakan dalam kegiatan menulis cerita, baik secara perseorangan maupun secara kelompok, (3) jika murid menulis sebuah cerita berdasarkan pengetahuannya atau hasil dari pengalamannya, guru kurang memberi bimbingan pada murid, kearah perbaikan yang lebih baik, kurangnya motivasi yang diberikan guru kepada murid agar keterampilan menulisnya dapat berkembang, guru kurang menggunakan media yang sifatnya inovatif dan kreatif yang melibatkan aktifitas mental, fisik maupun emosional.

Berdasarkan uraian di atas, adapun rumusan masalah dalam penelitian ini adalah: Apakah ada pengaruh penggunaan gambar seri terhadap keterampilan menulis cerita pada mata pelajaran bahasa Indonesia murid kelas III SD Inpres Bontokanang Kec.Galesong Kab.Takalar?. Untuk mengetahui pengaruh penggunaan gambar seri terhadap keterampilan menulis cerita pada mata pelajaran bahasa Indonesia murid kelas III SD Inpres Bontokanang Kec.Galesong Kab.Takalar

\section{Pengertian Media Gambar Seri (Media Visual)}

Kata media berasal dari bahasa latin yaitu medius yang secara harfiah 
yang berarti tengah, perantara, atau pengantar. Menurut Arsyad (2004 : 4) mengatakan bahwa istilah medium sebagai perantara yang mengantar informasi antara sumber dan penerima. Jadi, TV, film, foto, radio, rekaman audio, gambar, bahan-bahan cetakan, dan sejenis adalah media komunikasi. Hamidjojo ( Arsyad 2004) menyatakan bahwa "memberikan batasan media sebagai semua bentuk perantara yang di gunakan manusia untuk menyampaikan atau menyebar ide, gagasan, dan pendapat sehingga ide, gagasan atau pendapat yang dikemukakan itu sampai kepada penerima yang dituju". Djamarah (2006:124) mengemukakan bahwa Media gambar seri (media visual) adalah media yang hanya mengandalkan indera penglihatan .media visual ini ada yang menampilkan gambar diam sepert film strip (film rangkai),slide (film bingkai) foto,gambar atau lukisan,dan cetakan.adapula media visual yang menampilkan gambar atau simbol yang bergerak seperti film bisu, film kartun.

Dari penjelasan diatas jelaslah bahwa media gambar seri masuk dalam bagian media visual yang memungkinkann seorang guru dapat menggunakannya sebagai media didalam menyampaikan pesan pembelajaran agar pesan yang disampaikan lebih mudah dipahami. salah satu penyampaian pesan ini yaitu menggunakan gambar seri didalam meningkatkan keterampilan menulis cerita pada pelajaran bahasa Indonesia.

\section{Kelebihan dan Kelemahan Gambar Seri}

Adam (2010:18) mengemukakan kelebihan dan kekurangan Gambar seri sebagai berikut:

1) Sifatnya konkret, gambar lebih realities menujukkan pokok masalah dibandingkan dengan media verbal semata,

2) Gambarnya dapat membatasi batas ruang waktu,

3) Mudah digunakannya,

4) Lebih realitas,

5) Umumnya murah harganya,

6) Mudah didapat.

Namun demikian Media Gambar Seri juga memiliki keterbatasan, antara lain:

a) Semata-mata hanya medium visual,

b) Ukuran gambar sering kali tepat untuk pengajaran dalam kelompok besar,

c) Memerlukan ketersediaan sumber,

d) Keterampilan dan kejelian guru untuk dapat memanfaatkannya. 


\section{Penggunaan Media Gambar Seri dalam Meningkatkan Keterampilan Menulis Cerita}

Tujuan pengajaran menulis di SD menurut kurikulum pendidikan dasar 1994 tercermin dalam tujuan penggunaan (Mustakim dan Syamsudin, 2007:24), yakni (1) siswa mampu mengungkapkan gagasan, pendapat, pengalaman, informasi, pesan, dan perasaan secar tertulis, (2) siswa memiliki kegemaran menulis (3) siswa mampu memanfaatkan unsur-unsur kebahasaan dalam menulis.

Untuk mencapai tujuan tersebut guru dituntut mengupayakan strategi dan model pembelajaran yang baik serta ketepatan dalam menggunakan media dalam proses pembelajaran. Untuk itu pembelajaran hendaknya dikemas dalam aktivitas yang menarik, bermakna, bervariasi, menantang, dan sesuai dengan dunia anak. Untuk itu pembelajaran harus di bentuk sedemikian rupa sehingga tampak menyenangkan anak, misalnya dengan permainan, pengalaman praktis ataupun penggunaan media yang bisa menarik perhatian siswa yang sesuai dengan minat dan kebutuhan siswa. Dewasa ini keterampilan menulis siswa dikelas awal belum begitu mengembirakan. Kendala yang sering dihadapi dalam pembelajaran menulis salah satunya adalah penggunaan media pembelajaran yang kurang menerik perhatian siswa.

Penggunaan media dalam proses pembelajaran merupakan salah satu alternatif yang tepat didalam proses pembelajaran khususnya penggunaan media gambar seri di dalam keterampilan menulis cerita siswa kelas III.

Menurut sosialisasi KTSP 2006 (Halik. 2008: 46). Dengan menggunakan strategi diatas diharapakan dapat meningkatkan keaktifan siswa dalam pembelajaran sehingga keterampilan menulis cerita berdasarkan gambar seri dapat meningkat.

\section{Pengertian Menulis Cerita}

Susanto

(2013:246)

mengemukakan bahwa "menulis merupakan kegiatang yang paling sering dilakukan oleh setiap orang. Menulis membutuhkan keterampilan khusus yang harus dipelajari dan senantiasa dilatih. Menulis memerlukan keterampilan tambahan bahkan motivasi tambahan pula, hal ini dikarenakan menulis bukan bakat kerena tidak semua orang mampu untuk menulis". 
Tarigan( 1985: 2)

mengemukakan bahwa "menulis adalah menurunkan, menirukan atau melukiskan lambang-lambang grafik yang menggambarkan suatu bahasa yang dipahami oleh seseorang, sehingga orang lain tersebut dapat membaca lambang-lambang grafik tersebut, sehingga mereka dapat memahami bahasa dan gambaran grafik itu". hal ini sejalan dengan Aburrahman dan Waluyo (2000: 23) mengemukakan bahwa "menulis adalah penggambaran visual tentang pikiran, perasaan, dan ide dengan menggunakan bahasa tulis untuk keperluan komunikasi atau menyampaikan pesan tertentu".

$$
\text { Tarigan }
$$

(1982:

mengemukakan bahwa "menulis merupakan suatu keterampilan berbahasa yang dipergunakan untuk berkomunikasi secara tidak langsung, tidak secara tatap muka dengan orang lain".

Pengertian menulis juga dikemukakan oleh Suparno dan Yunus (2007:4) dinyatakan bahwa "menulis adalah aktivitas menyampaikan pesan dengan menggunakan tulisan sebagai medianya".

Beberapa definisi tentang menulis telah diungkapkan oleh para ahli. Tarigan (Susanto,2013:247), berpendapat bahwa "menulis merupakan suatu kegiatan yang produktif dan eksprfesif". Dalam kegiatan menulis ini, penulis harus terampil memanfaatkan struktur bahasa dan kosakata. Keterampilan menulis ini tidak akan datang secara otomatis, harus melalui latihan dan praktik yang banyak dan teratur.

Dalam upaya meningkatkan keterampilan menulis cerita khususnya di kelas III maka perlu adanya rambu rambu di dalam menilai sejauh mana tingkat keberhasilan yang dilakukan oleh seorang guru didalam mengajarkan penggunaan media gambar seri dalam meningkatan keterampilan menulis cerita siswa. Adam (2010 : 18) untuk melihat tingkat keterampilan menulis cerita berdasarkan gambar seri dari siswa maka hal-hal yang dinilai sebagai berikut: 1)Pengembangan topik (logis, relvan, dan jelas) 2) pengorganisasian isi (runtut, utuh, dan koheren) 3) struktur (morfologi, sintaksis) 4) pililhan kata (diksi) 5) penerapan ejaan dan kerapian.

\section{METODE PENELITIAN}

Penelitian ini merupakan penelitian eksperimen yaitu jenis One-Group Pretest-Posttest Design. Dalam penelitian ini, hasil perlakuan dapat 
diketahui lebih akurat, karena dapat membandingkan dengan keadaan sebelum diberi perlakuan (treatment).

Populasi penelitian ini adalah keseluruhan murid kelas III SD Inpres Bontokanang, Kec. Galesong, Kab. Takalar. Jumlah murid SD Inpres Bontokanang adalah 116 orang.Sampel dalam penelitian ini adalah kelas III yang berjumlah 20 orang. Adapun instrumen yang digunakan dalam penelitian ini adalah lembar test. Teknik tes dalam penelitian ini adalah melakukan tes hasil belajar sebanyak dua kali, yaitu sebelum diberikan perlakuan (pre-test) dan setelah diberikan perlakuan (post-tes). Untuk menganalisi data yang diperoleh dari hasil penelitian akan digunakan analisis statistic deskriptif dan inferensial.

\section{HASIL PENELITIAN DAN PEMBAHASAN}

Berdasarkan hasil pre test nilai ratarata hasil belajar murid 60,75 dengan kategori yakni sangat rendah yaitu 5\% rendah 35\% sedang 55\% tinggi 5\% dan sangat tinggi berada pada persentase 0 . Melihat dari hasil presentse yang ada dapat dikatakan bahwa tingkat keterampilan berbicara murid sebelum diterangkan metode diskusi tergolong mudah.
Selanjutnya nilai rata-rata hasil pree test adalah 78,28 Jadi keterampilan menulis cerita murid setelah ditetapkan maka gambar seri mempunyai hasil belajar yang lebih baik dibanding dengan sebelum penerapan media gambar seri. Selain itu persentasi kategori hasil belajar bahasa indonesia murid juga meningkat yakni sangat tinggi yaitu 35\%, tinggi 30\%, sedang $35 \%$, rendah $5 \%$, dan sangat rendah berada pada presentase $0 \%$.

Berdasarkan hasil analisis statistik inferensial dengan menggunakan rumus uji $t$, dapat diketahui bahwa nilai $\mathrm{t}$ hitung sebesar 9,30. Dengan frekuensi ( $\mathrm{dk}$ ) sebesar 20 - $1=19$, pada taraf signifikansi 5\%, maka diperoleh $t_{\text {tabel }}=2,09$. Oleh karena itu $t_{\text {hitung }}>t_{\text {tabel }}$ taraf signifikan $0,05 \%$ maka hipotesis nol $\left(\mathrm{H}_{0}\right)$ ditolak dan hipotesis alternatif $\left(\mathrm{H}_{1}\right)$ diterima yang berarti bahwa ada pengaruh dalam menerapkan media gambar seri terhadap ketrampilan menulis cerita.

Hasil analisis diatas yang menunjukan adanya pengaruh penggunaan gambar seri terhadap keterampilan menulis cerita, sejalan dengan hasil observasi yang dilakukan. Berdasrkan hasil observasi terdapat perubahan pada murid yaitu pada awal kegiatan pembelajaran ada beberapa 
murid yang melakukan kegiatan lain atau bersikap cuek selama kegiatan pembelajaran berlangsung. Hal ini dapat dilihat pada pertemuan pertama murid yang melakukan kegiatan lain sebanyak 3 orang, sedangkan pada pertemuan terakhir hanya1 murid yang melakukan kegiatan lain pada saat media gambar seri berlangsung. Pada awal pertemuan, hanya sedikit murid yang atif mengikuti pembelajaran. Akan tetapi sejalan dengan diterapkannya media gambar seri murid mualai aktif pada setiap pertemuan.

Hasil observasi menunjukan banyaknya jumlah murid yang menjawab pada saat diajukan pertanyaan dan murid yang mengajukan diri untuk menyampaikan persoalan faktual. Murid juga mulai aktif dan percaya diriuntuk menyampaikan perasaan dan pendapatnya setelah melakukan kegiatan menulis cerita, maka mengaku senang dan sangat menikmati media gambar yang dilakukan sehingga termotivasi untuk mengikuti pelajaran. Proses pembelajaran yang menyenangkan membuat murid tidak lagi keluar masuk pada saat pembelajaran berlangsung dan tidak lagi merasa bosan tertekan ketika mengikuti proses pembelajaran di kelas.
Berdasarkan hasil analisis statistik, deskriptif dan analistik inferensial yang diperoleh serta hasil observasi yang telah dilakukan dapat disimpulkan bahwa ada pengaruh media gambar seri terhadap keterampilan menulis cerita siswa pada mata pelajaran bahasa indonesia, murid kelas III SD Inpres Bontokanang, Kec.Galesong, Kab.Takalar

Untuk menghitung korelasi product moment ini dilakukan dengan dua cara yaitu dengan cara manual dan di bantu dengan program SPSS 23.0 for Windows. Adapun dengan cara manual, penulis membuat tabel-tabel penolong untuk memudahkan dalam menghitung nilai $\mathrm{r}_{\text {hitung }}$ yang telah diperoleh, kemudian di konsultasikan dengan nilai $r_{\text {tabel }}$ product moment. Adapun data yang di analisis adalah minat belajar (X) dan presatasi belajar bahasa Indonesia (Y).

\section{KESIMPULAN}

Simpulan yang lebih rinci berkaitan pelaksanaan media gambar seri terhadap keterampilan menulis cerita pada murid kelas III SD Inpres Bontokanang Kec.Galesong Kab.Takalar bahwa berdasarkan data yang diperoleh dapat disimpulkan bahwa secara umum keterampilan menulis pada murid kelas 
III SD Inpres Bontokanang Kec.Galesong Kab.Takalar sebelum penerapan media gambar seri dikategorikan rendah hal ini ditunjukan dari perolehan persentase hasil belajar murid, yaitu sangat rendah 5\%, rendah 35\%, sedang $55 \%$, tinggi 5\%, dan sangat tinggi berada pada persentase 0\%. Secara umum media gambar seri berpengaruh terhadap keterampilan menulis cerita pada murid kelas III SD Inpres Bontokanang Kec.Galesong Kab.Takalar dapat dilihat dari perolehan persentase yaitu sangat rendah tinggi 35\%, tinggi $30 \%$, sedang 30\%,rendah 5\%, dan sangat rendah berada pada persentase 0\%. Penerapan media gambar seri berpengaruh terhadap keterampilan menulis cerita setelah diperoleh $\mathrm{t}$ hitung 9,30 dan $t$ tabel 2, 09 maka diperoleh $t$ hitung $>t_{\text {tabel }}$ atau 9,30>2,09.

Berdasarkan temuan yang dikaitkan hasis penelitian bahwa penerapan media gambar seri berpengaruh terhadap keterampilan menulis cerita pada murid kelas III SD Inpres Bontokanang Kec.Galesong Kab.Takalar. Maka ditemukan beberapa saran sebagai berikut: (1) Kepada para pendidik khususnya guru SD Inpres Bontokanang Kec.Galesong Kab.Takalar disarankan menerapkan media gambar untuk membangkitkan minat dan motivasi murid untuk belajar. (2) Kepada peneliti, diharapkan mampu mengambangkan media gambar seri ini dengan menerapkan pada materi lain untuk mengetahui apakah pada materi lain cocok dengan metode pembelajaran ini demi tercapainya tujuan yang diharapkan. (3)Kepada calon peneliti, akan dapat mengembangkan dan memperkuat metode ini serta memperkuat hasil penelitian ini dengan cara mengkaji terlebih dahulu dan mampu mengadakan penelitian yang lebih sukses.

\section{DAFTAR PUSTAKA}

Abduh, Amir 2007. Media Pembelajaran. Makassar: PGSD.

Arikunto,suharsini 2001. Dasar-dasar Evaluasi Pendidikan. Jakarta: Bumi Aksara.

Abdurahman dan Waluyo. 2000. Pendidikan Anak Bermasalah. Yogyakarta: Pustaka Pelajar.

Akhadiah.1991. Menulis 1. Jakarta: Universitas Terbuka.

Arsyad, Azhar. 1995. Media Pengajaran. Jakarta: PT Raja Grapindo Persada.

Depdiknas, 2006. Kurikulum Tingkat Satuan Pendidikan Pengajaran Bahasa Indonesia Sekolah Dasar. Jakarta : Depdiknas. 
Djamarah, Syaiful Bahri dan Aswan Zain. 2006. Strategi Belajar Mengajar. Jakarta: Rineka Cipta.

Emzir. 2008. Metodologi Penelitian Pendidikan. Jakarta: PT Rajagrafindo Persada.

Halik, Abdul dan Muh. Faisal. 2008. Pengembangan Pembelajaran Bahasa Indonesia. Makassar PGSD.

Latuheru, John D. 2003. Media Pengajaran. Jakarta: Direktorat Jenderal Pendidikan Tinggi.

Mulyono. 2003. Pendidikan Bagi Anak yang Berkesulitan Belajar. Jakarta: Rineka Cipta.

Sunarti, Subana. 2006. Strategi Belajar Mengajar Bahasa Indonesia. Bandung: PT Pustaka Setia.

Suparno dan Yunus.2007. Ketrampilan Dasar Menulis. Jakarta: Universitas Terbuka.

Sudjana, dkk. 1990. Media Pengajaran. Bandung: Sinar Baru.

Syafi'Ie, Iman. 1999. Pengajaran Membac dan menulis di Kelas Awal Sekolah Dasar. Malang: Departemen Pendidikan dan Kebudayaan.

Susanto, Ahmad.2013. Teori Belajar dan Pembelajaran di Sekolah Dasar. Jakarta: PrenadaMedia Group.
Tarigan Djago dan H, G, Tarigan. 1986. Teknik Pengajaran Keterampilan Berbahasa. Bandung: Angkasa.

Uny. 2008. Tujuan Menulis, (online) http:/eprints.uny.ac.id/9902/3//b ab\%202\%20\%2008108247081.pdf. diakses pada tanggal 5 juli 2016.

Uny. 2012. Pengertian Menulis. (online) (http:/eprints.uny.ac.id/8133/3// BAB\%202\%20\%07201241038.pdf. diakses pada tanggal 5 juli 2016.

Eviy. 2013. Keterampilan Menulis di SD. (online)

(http://catatacsieviy.blogspot.com /2013/04/keterampilan-menulisdi-sd.html. Diakses pada tanggal 7 juli 2016.

Kelayu. 2014. Manfaat Media Gambar. (online)

(http://milkelayu.blogspot.com/2 014/01/normal-o-false-false-enusx-none.html. Diakses 7 Juli 2016.

Tim Prima Pena. 2007. Kamus Besar Bahasa Indonesia. Jakarta: Gita Media Pres.

Wibawa, Basuki dan Mukti, Farida. 1992. Media Pengajaran. Jakarta: PT. 